\title{
Analisis Metode Certainty Factor pada Sistem Pakar Diagnosa Penyakit THT
}

\author{
Khairina Eka Setyaputri ${ }^{1}$, Abdul Fadlil ${ }^{2}$, dan Sunardi ${ }^{3}$ \\ ${ }^{1,2}$ Program Studi Magister Teknik Informatika \\ Universitas Ahmad Dahlan, Yogyakarta, Indonesia \\ ${ }^{3}$ Program Studi Teknik Elektro \\ Universitas Ahmad Dahlan, Yogyakarta, Indonesia \\ khairinaputri1@gmail.com ${ }^{1}$,fadlil@mti.uad.ac.id ${ }^{2}$,sunardi@mti.uad.ac.id ${ }^{3}$
}

\begin{abstract}
There are two factors that cause a disease, called Congenital and Acquired. Congenital refers to a disease a person is born with, while Acquired refers to a disease acquired after a person was born such as infection, trauma, and neoplasm. The infected person will sometimes require information on the disease before going to the doctor or a hospital. Such information may be found from a system which receives input on the symptoms and gives a clear information on the corresponding disease. This may be achieved via a system of experts, in which the expert refers to an ENT (Ear, Nose, and Throat) specialist. Such information is hoped to provide a solution on the disease. The system of ENT specialists designed and research in this paper used the certainty factor method. The method will overcome the uncertainty in decision making depending on the symptoms described by the user. This paper is successfully applied certainty factor method used as an instrument of decision making in the system of ENT specialists. The system is web-based, enabling the user to access and choose the symptoms of the disease as well as acquiring information on ENT diseases easly.
\end{abstract}

Keywords-Certainty Factor, ENT (Ear, Nose, and Throat), expert system, web

\begin{abstract}
Abstrak- Faktor dan penyebab suatu penyakit ada dua yaitu Kongenital dan Acquired. Kongenital merupakan penyakit bawaan sejak lahir dan Acquired merupakan penyakit yang didapat setelah lahir (penyakit yang bukan bawaan sejak lahir) seperti infeksi, trauma, Neoplasma (keganasan/tumor). Penderita suatu penyakit terkadang membutuhkan informasi mengenai penyakit yang dialami sebelum memutuskan untuk berobat ke dokter atau rumah sakit. Informasi tersebut bisa didapatkan melalui sistem yang dapat menerima inputan berupa gejala penyakit dan memberikan informasi yang jelas mengenai penyakit tersebut. Hal ini dapat dilakukan menggunakan sistem pakar, dalam kasus ini pakar merupakan dokter spesialis THT (Telinga, Hidung, dan Tenggorokan). Informasi tersebut diharapkan memiliki solusi dari penyakit yang diderita. Sistem pakar penyakit THT yang dirancang dan diteliti pada penelitian ini menggunakan metode certainty factor. Metode ini dapat mengatasi ketidakpastian dalam pengambilan keputusan berdasarkan gejala-gejala yang dirasakan atau diinputkan oleh user. Penelitian ini telah berhasil dan tepat menerapkan metode certainty factor sebagai alat pengambilan keputusan pada sistem pakar penyakit THT. Sistem ini berbasis web, sehingga user dapat dengan mudah mengakses dan memilih gejala yang dirasakan serta mencari informasi mengenai penyakit THT.
\end{abstract}

Kata kunci-Certainty Factor, sistem pakar, THT (Telinga, Hidung, dan Tenggorokan), web

\section{PENDAhUluan}

Faktor penyebab penyakit ada dua yaitu Kongenital dan Acquired. Kongenital adalah penyakit bawaan sejak lahir, sedangkan Acquired adalah penyakit yang didapat (bukan bawaan sejak lahir) seperti infeksi, trauma, Neoplasma (keganasan/tumor), dan alergi. Berdasarkan Sosiodemografi, sekitar $47,80 \%$ pasien rawat inap yang menderita penyakit Telinga, Hidung, dan Tenggorokan (THT) banyak terjadi di provinsi Manado [1]. Insiden sinusitis merupakan penyakit yang cukup parah yang membuat orang memeriksa diri ke dokter yaitu antara 1,3 dan 3,5 per 100 kasus orang dewasa per tahun [2].

Penyakit THT sering dianggap remeh oleh sebagian masyarakat di Indonesia, tetapi jika penyakit tersebut tidak segera ditangani akan menimbulkan penyakit-penyakit yang lain. Sebagai contoh adalah batuk dan pilek yang terkadang tidak diperhatikan oleh masyarakat, batuk disebabkan karena faktor cuaca dan kondisi tubuh yang kurang sehat, begitu juga dengan pilek. Gejala batuk dan pilek jika tidak segera ditangani maka penderita akan mengalami telinga berair atau secara umum disebut congekan. Hal tersebut terjadi karena kurangnya informasi.

Informasi saat ini sudah sangat mudah untuk didapatkan, hanya saja perlu adanya media atau akses yang mudah dalam mendapatkan informasi yang benar yang bersumber dari pakar atau orang yang ahli dalam bidang tertentu. Seorang penderita penyakit membutuhkan informasi mengenai penyakit yang dideritanya sebelum berkonsultasi dengan dokter, sehingga dibutuhkan akses informasi yang mudah bagi penderita untuk 
mengetahui penyakit yang diderita. Salah satunya dengan adanya sistem pakar untuk mendiagnosa penyakit berdasarkan gejala yang dirasakan oleh penderita, yang kemudian menghasilkan informasi mengenai penyakit tersebut.

Sistem pakar (expert system) merupakan sistem yang berusaha untuk mengadopsi kemampuan atau pengetahuan manusia ke dalam komputer, agar komputer dapat bekerja dalam menyelesaikan suatu masalah seperti layaknya seorang pakar atau sesorang yang mempunyai keahlian dalam bidang tertentu, yaitu pakar yang mempunyai knowledge atau kemampuan khusus yang tidak diketahui dan dimiliki oleh orang lain. Sistem pakar merupakan cabang dari Artificial Intelligence (AI) [3].

Penelitian dengan tema sejenis yaitu sistem pakar diagnosa penyakit telah banyak diteliti pada penelitian sebelumnya [4] - [11]. Salah satunya adalah sistem pakar diagnosa penyakit pada saluran pernafasan dan paru dapat mengidentifikasi penyakit dengan mendokumentasikan informasi atau pengetahuan dari pakar dengan metode pencarian kesimpulan menggunakan metode Certainty Factor (CF) [4]. Penelitian lainnya adalah sistem pakar yang digunakan untuk mendiagnosa jenis penyakit stroke dengan metode CF digunakan untuk mendapatkan nilai kepastian [5].

Sistem pakar tidak hanya digunakan untuk mendiagnosa penyakit pada manusia tapi juga dapat digunakan sebagai diagnosa penyakit pada tanaman yaitu diagnosa hama anggrek coelogyne pandurata dengan metode penerapannya adalah metode forward chaining dan CF [6]. Metode CF juga digunakan dalam sistem pakar diagnosa hama dan penyakit pada tanaman bawang merah [7], hasil yang diperoleh adalah masih kurangnya pakar yang dapat memberikan informasi mengenai solusi terbaik dalam permasalahan yang ada. Sistem pakar dapat juga digunakan untuk mendiagnosa penyakit pada kelinci menggunakan metode teorema bayes dengan menghitung probabilitas dari setiap penyakit pada kelinci [8]. Terdapat juga sistem pakar diagnosa penyakit pada tanaman jagung menggunakan metode bayes dalam menentukan pilihan pengobatan [9].

Sistem pakar dapat membantu Tim Medis dalam mendiagnosa suatu penyakit, khususnya penyakit THT berdasarkan gejala-gejala yang dikeluhkan, untuk performa yang lebih baik sistem pakar membutuhkan lebih banyak rule [10]. Penelitian sistem pakar untuk mendiagnosa penyakit THT telah dilakukan mengunakan metode Depth First Search, hasil akhir dalam penelitian ini adalah penyakit THT yang diderita beserta saran pengobatan dengan tanaman obat [11].

Dari uraian di atas metode CF dapat digunakan sebagai metode dalam pengambilan keputusan pada bidang kesehatan untuk mendiagnosa suatu penyakit. Pada penelitian ini dilakukan analisis metode CF pada Sistem Pakar Penyakit THT berbasis website.

\section{Metodologi Penelitian}

Alur kerja Sistem Pakar Penyakit THT pada menu diagnosa ditunjukkan pada Gambar 1. Menu diagnosa digunakan oleh pengguna untuk memilih gejala-gejala yang dirasakan. Dalam proses diagnosa jika pengguna ingin mengulang input gejala maka proses akan dimulai kembali dari tampilan input gejala. Jika pengguna telah memilih gejala tersebut langkah selanjutnya adalah menampilkan hasil diagnosa. Hasil diagnosa berisi penyakit yang diderita oleh pengguna.

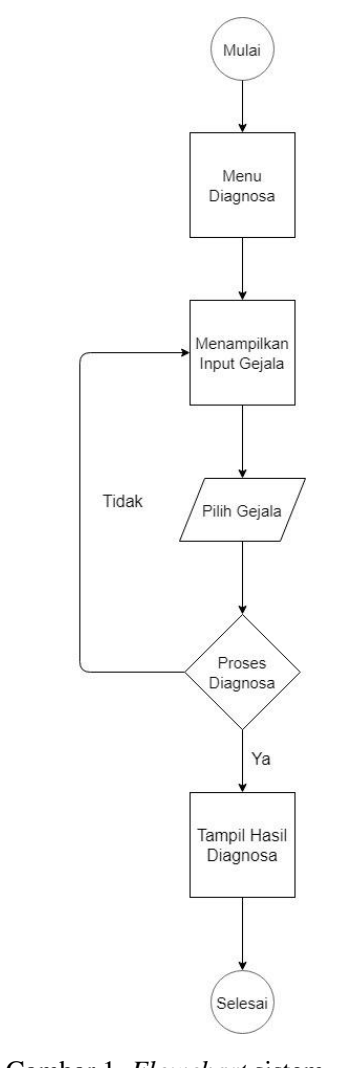

Gambar 1. Flowchart sistem

Metode CF menunjukkan ukuran kepastian terhadap suatu fakta atau aturan. CF merupakan nilai parameter klinis yang diberikan MYCIN untuk menunjukkan besarnya kepercayaan. Kelebihan dari metode CF adalah dapat mengukur sesuatu yang pasti atau tidak pasti dalam pengambilan keputusan pada sistem pakar diagnosa penyakit [12]. Rumus dasar CF [13]:

$$
C F(h, e)=M B(h, e)-M D(h, e)
$$

Keterangan:

$\mathrm{CF}(\mathrm{h}, \mathrm{e})=$ Certainty Factor (faktor kepastian) dalam hipotesis $\mathrm{h}$ dipengaruhi oleh evidence (gejala) e.

$\mathrm{MB}(\mathrm{h}, \mathrm{e})=$ Measure of Belief (tingkat keyakinan), merupakan ukuran kepercayaan dari hipotesis $\mathrm{h}$ dipengaruhi oleh evidence (gejala) e.

$\mathrm{MD}(\mathrm{h}, \mathrm{e})=$ Measure of Disbelief (tingkat ketidakyakinan), merupakan ukuran ketidakpercayaan dari hipotesis $\mathrm{h}$ dipengaruhi oleh gejala e.

$\mathrm{h}=$ Hipotesa atau konklusi yang dihasilkan (antara 0 dan 1).

e $\quad=$ Evidence atau peristiwa atau fakta (gejala)

Perhitungan selanjutnya adalah kombinasi dua atau lebih rule dengan evidence berbeda tetapi dalam hipotesis yang sama:

$$
\begin{array}{ll}
\text { Rule } 1 & C F\left(h, e_{1}\right)=C F_{1}=C\left(e_{1}\right) x C F(\text { Rule } 1) \\
\text { Rule } 2 & C F\left(h, e_{2}\right)=C F_{2}=C\left(e_{2}\right) x C F(\text { Rule } 2)
\end{array}
$$

CFkombinasi $\left[C F_{1}, C F_{2}\right]=C F_{1}+C F_{2}\left(1-C F_{1}\right)$ 


\section{HASIL DAN PEMBAHASAN}

\section{A. Basis Pengetahuan}

Gejala penyakit THT yang dirasakan oleh pasien ditunjukkan pada Tabel I. Jenis penyakit THT difokuskan hanya pada jenis penyakit yang sering dikeluhkan oleh pasien THT, yaitu Otitis Media Akut, Serumen, Otitis Eksterna, Sinusitis, dan Rhinitis Kronis. Kode jenis penyakit dan jenis penyakit ditunjukkan pada Tabel II.

TABEL I. GEJALA PENYAKIT

\begin{tabular}{|l|l|}
\hline Kode & \multicolumn{1}{|c|}{ Gejala Penyakit } \\
\hline G001 & Batuk \\
\hline G002 & Bersin \\
\hline G003 & Dahak mengalir ditenggorok \\
\hline G004 & Demam \\
\hline G005 & Hidung mampet \\
\hline G006 & Hidung mampet pada hidung bagian sebelah \\
\hline G007 & Hidung mampet pada bagian sebelah secara bergantian \\
\hline G008 & Ingus bau \\
\hline G009 & Memiliki riwayat mengorek telinga \\
\hline G010 & Penciuman berkurang \\
\hline G011 & Pendengaran berkurang \\
\hline G012 & Pilek encer di kedua hidung \\
\hline G013 & Pilek \\
\hline G014 & Sakit kepala \\
\hline G015 & Telinga berair selama $\geq 2$ bulan \\
\hline G016 & Telinga berair selama $\leq 2$ bulan \\
\hline G017 & Telinga berair bau selama $\geq 2$ bulan \\
\hline G018 & Telinga mampet \\
\hline G019 & Telinga gatal \\
\hline G020 & Telinga nyeri \\
\hline G021 & Tenggorok nyeri \\
\hline G022 & Telinga nyeri saat mengunyah \\
\hline G023 & Telinga berdengung \\
\hline G024 & Tidur mendengkur \\
\hline
\end{tabular}

TABEL II. JENIS PENYAKIT

\begin{tabular}{|l|l|}
\hline Kode & \multicolumn{1}{c|}{ Jenis Penyakit } \\
\hline P001 & Otitis Media Akut (OMA) \\
\hline P002 & Serumen (Kotoran Telinga) \\
\hline P003 & Otitis Eksterna (OE) \\
\hline P004 & Sinusitis \\
\hline P005 & Rhinitis Kronis \\
\hline
\end{tabular}

\section{B. Rule $\mathrm{CF}$}

Penerapan metode CF pada sistem pakar memerlukan beberapa rule berupa variabel (gejala dengan simbol G) dan nilai bobot yang diberikan oleh pakar. Data sampel penyakit pasien diperoleh dari data rekam medis pasien penyakit THT oleh dr. M. Agus Sugicharto Sp.THT periode bulan Februari 2018. Nilai bobot dibutuhkan untuk setiap gejala pada setiap penyakit. Pakar memberikan skala nilai bobot untuk tiap gejala antara $0,2-1,0$. Rule CF yang berisi gejala dan nilai bobot dari pakar untuk setiap penyakit ditunjukkan pada Tabel III.

TABEL III. RULE

\begin{tabular}{|l|l|}
\hline No & \multicolumn{1}{|c|}{ Rule } \\
\hline 1 & $\begin{array}{l}\text { IF G001 }(0,8) \text { AND G004 (0,8) AND G011 }(0,6) \text { AND } \\
\text { G013 }(0,8) \text { AND G014 }(0,4) \text { AND G016 }(0,8) \text { AND } \\
\text { G020 }(1,0) \text { AND G023 }(0,6) \text { THEN P001 }\end{array}$ \\
\hline 2 & $\begin{array}{l}\text { IF G009 }(0,4) \text { AND G011 }(0,8) \text { AND G018 }(1,0) \text { AND } \\
\text { G019 }(0,2) \text { THEN P002 }\end{array}$ \\
\hline 3 & $\begin{array}{l}\text { IF G009 }(0,8) \text { AND G011 }(0,8) \text { AND G016 }(0,4) \text { AND } \\
\text { G018 }(0,6) \text { AND G019 }(0,8) \text { AND G020 }(1,0) \text { AND } \\
\text { G023 }(0,6) \text { THEN P003 }\end{array}$ \\
\hline 4 & $\begin{array}{l}\text { IF G001 }(0,4) \text { AND G003 }(0,8) \text { AND G004 }(0,4) \text { AND } \\
\text { G005 }(0,4) \text { AND G006 }(0,6) \text { AND G010 }(0,6) \text { AND } \\
\text { G012 }(0,6) \text { AND G014 }(1,0) \text { THEN P004 }\end{array}$ \\
\hline 5 & $\begin{array}{l}\text { IF G010 }(0,6) \text { AND G007 (0,8) AND G012 }(1,0) \text { AND } \\
\text { G013 }(1,0) \text { AND G005 }(0,8) \text { AND G002 }(0,8) \text { AND } \\
\text { G014 }(0,4) \text { THEN P005 }\end{array}$ \\
\hline
\end{tabular}

\section{Implementasi}

Tampilan input gejala diagnosa ditunjukkan pada Gambar 2. Tampilan input gejala diagnosa digunakan pengguna untuk menginputkan gejala-gejala yang dirasakan. Pengguna memilih 1 jawaban dari 5 pilihan jawaban yaitu Ragu-ragu (0,2), Mungkin (0,4), Sangat Mungkin $(0,6)$, Hampir Pasti $(0,8)$, dan Pasti $(1,0)$ pada setiap gejala yang dirasakan.

Tampilan hasil diagnosa ditunjukkan pada Gambar 3. Tampilan hasil diagnosa menampilkan kemungkinankemungkinan pengguna mengalami penyakit berdasarkan gejala yang telah diinputkan sebelumnya.

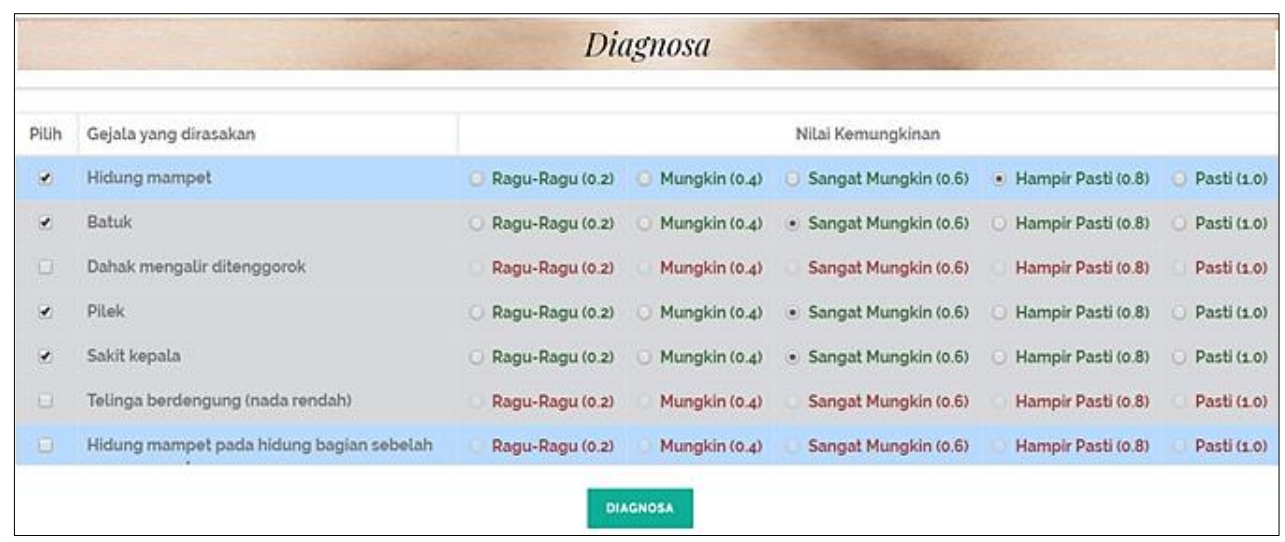

Gambar 2. Tampilan input gejala diagnosa 


\begin{tabular}{|c|c|c|c|c|c|}
\hline \multicolumn{6}{|c|}{ Hasil Diagnosa } \\
\hline \multirow{2}{*}{\multicolumn{6}{|c|}{$\begin{array}{l}\text { Kemungkinan Ke-1 Anda Mengalami Penyakit Sinusitis } \\
\text { CF1 untuk iterasi pertama adatah } 0\end{array}$}} \\
\hline & & & \multicolumn{3}{|c|}{ CF1 untuk iterasi pertama adalaho 0} \\
\hline Iterasi & Nama Gojala & Nilai User [NU! & Nilai Sistem [NS] & NU'NSICF2l & $C F_{1} \cdot\left\langle C F_{2}^{\prime}\left(1=C F_{1}\right)\right\}\left[C F_{1}\right]$ \\
\hline 1 & Batuk & 06 & 04 & $0.6 \cdot 0.4 \cdot 02400$ & $0.102400^{\prime}(1.0 .1) \cdot 0.2400$ \\
\hline 2 & Sakit kepala & 0.6 & 1 & $0.6 \% .0 .6000$ & $0.2400 \cdot 10.60000^{\prime}(1-0.24000) \cdot 0.6960$ \\
\hline 3 & Plek & 0.6 & 0.8 & $06 \cdot 0.8 \cdot 0.4800$ & $0.6960 \cdot 10.4800 * 11-0.696011 \cdot 0.8419$ \\
\hline 4 & Hidung mampet & 08 & 00 & 08.08 .04800 & $0.84: 9 \cdot 10.4800 \cdot(1-0.84: 91) \cdot 0.9178$ \\
\hline \multicolumn{6}{|c|}{ Nilai CF Akhir $=0.917^{8}$} \\
\hline \multicolumn{6}{|c|}{ Kemungkinan Ke-2 Anda Mengalami Penyakit Rhinitis Kronis } \\
\hline \multicolumn{6}{|c|}{ CF1 untuk iterasi pertama adalah 0} \\
\hline Iterasi & Nama Gejala & Nitai User DNUI & Nilai Sistem [NS] & NU - NS [CFa] & $\left.\mathrm{CF}_{1} \cdot\left(\mathrm{CF}_{2}{ }^{*}\left(1-\mathrm{CF}_{1}\right)\right] \mathrm{CF}_{1}\right]$ \\
\hline 1 & Sakit kopata & 06 & 04 & $06^{\circ} 0.4 \cdot 02400$ & $0 \cdot 102400^{\circ}(1 \cdot 0) \cdot 0.2400$ \\
\hline 2 & Hidung mampot & 08 & 08 & $0.8 \cdot 08 \cdot 05400$ & $0.2400 \cdot 10,6400^{\circ}(1 \cdot 0.240011 \cdot 0,7264$ \\
\hline 3 & Alek & 0.6 & 1 & $0.6^{\prime} 1.0 .6000$ & $0.7264 \cdot 10.6000^{*}(1-0.7264) \cdot 0.8906$ \\
\hline
\end{tabular}

Gambar 3. Hasil diagnosa

TABel IV. Perkalian Nilai Bobot User (BU) Dengan Nilai Bobot Pakar (BP) atau Rule

\begin{tabular}{|c|c|c|c|c|c|c|c|c|}
\hline \multicolumn{9}{|c|}{ Pasien A } \\
\hline \multicolumn{5}{|c|}{ Kemungkinan 1 = Sinusitis } & \multicolumn{4}{|c|}{ Kemungkinan 2 = Rhinitis Kronis } \\
\hline No & Kode Gejala & $\mathbf{B U}$ & $\mathbf{B P}$ & $\begin{array}{c}\mathbf{B U} * \mathbf{B P} \\
(\mathbf{C F})\end{array}$ & Kode Gejala & BU & $\mathbf{B P}$ & $\begin{array}{c}\mathbf{B U} * \mathbf{B P} \\
(\mathbf{C F})\end{array}$ \\
\hline 1 & G001 & 0,6 & 0,4 & 0,24 & G014 & 0,6 & 0,4 & 0,24 \\
\hline 2 & G014 & 0,6 & 1,0 & 0,60 & G005 & 0,8 & 0,8 & 0,64 \\
\hline 3 & G013 & 0,6 & 0,8 & 0,48 & G013 & 0,6 & 1,0 & 0,60 \\
\hline 4 & G005 & 0,8 & 0,6 & 0,48 & & & & \\
\hline \multicolumn{9}{|c|}{ Pasien B } \\
\hline \multicolumn{5}{|c|}{ Kemungkinan 1 = Serumen } & \multicolumn{4}{|c|}{ Kemungkinan 2 = Otitis Eksterna } \\
\hline No & Kode Gejala & BU & $\mathbf{B P}$ & $\begin{array}{c}\mathbf{B U} * \mathbf{B P} \\
(\mathbf{C F})\end{array}$ & Kode Gejala & BU & $\mathbf{B P}$ & $\begin{array}{c}\mathbf{B U} * \mathbf{B P} \\
(\mathbf{C F})\end{array}$ \\
\hline 1 & G018 & 0,8 & 1,0 & 0,80 & G019 & 0,6 & 0,8 & 0,48 \\
\hline 2 & G011 & 0,8 & 0,8 & 0,64 & G009 & 0,6 & 0,8 & 0,48 \\
\hline 3 & G009 & 0,6 & 0,4 & 0,24 & G011 & 0,8 & 0,8 & 0,64 \\
\hline 4 & G019 & 0,6 & 0,2 & 0,12 & G018 & 0,8 & 0,6 & 0,48 \\
\hline \multicolumn{9}{|c|}{ Pasien C } \\
\hline \multicolumn{5}{|c|}{ Kemungkinan 1 = Otitis Eksterna } & \multicolumn{4}{|c|}{ Kemungkinan 2 = Serumen } \\
\hline No & Kode Gejala & BU & BP & $\begin{array}{c}\mathbf{B U} * \mathbf{B P} \\
(\mathbf{C F})\end{array}$ & Kode Gejala & BU & $\mathbf{B P}$ & $\begin{array}{c}\mathbf{B U} * \mathbf{B P} \\
(\mathbf{C F})\end{array}$ \\
\hline 1 & G020 & 0,6 & 1,0 & 0,60 & G018 & 0,8 & 1,0 & 0,80 \\
\hline 2 & G019 & 0,6 & 0,8 & 0,48 & G009 & 0,6 & 0,4 & 0,24 \\
\hline 3 & G009 & 0,6 & 0,8 & 0,48 & G019 & 0,6 & 0,2 & 0,12 \\
\hline 4 & G018 & 0,8 & 0,6 & 0,48 & & & & \\
\hline \multicolumn{9}{|c|}{ Pasien D } \\
\hline \multicolumn{5}{|c|}{ Kemungkinan 1 = Rhinitis Kronis } & \multicolumn{4}{|c|}{ Kemungkinan 2 = Sinusitis } \\
\hline No & Kode Gejala & BU & BP & $\begin{array}{c}\mathbf{B U} * \mathbf{B P} \\
(\mathbf{C F})\end{array}$ & Kode Gejala & BU & $\mathbf{B P}$ & $\begin{array}{c}\mathbf{B U} * \mathbf{B P} \\
(\mathbf{C F})\end{array}$ \\
\hline 1 & G012 & 0,8 & 1,0 & 0,80 & G014 & 0,8 & 1,0 & 0,80 \\
\hline 2 & G002 & 0,6 & 0,8 & 0,48 & G012 & 0,8 & 0,8 & 0,64 \\
\hline 3 & G007 & 0,6 & 0,8 & 0,48 & & & & \\
\hline 4 & G014 & 0,8 & 0,4 & 0,32 & & & & \\
\hline
\end{tabular}




\section{Pembahasan Perhitungan Aplikasi}

Pembahasan dibutuhkan untuk mengetahui langkah dan hasil dalam penelitian ini, maka dibutuhkan perhitungan yang dapat membantu dalam memberikan diagnosa pada penderita penyakit THT. Metode perhitungan pada sistem dalam penelitian ini menggunakan metode $\mathrm{CF}$.

Langkah pertama penggunaan metode $\mathrm{CF}$ dalam proses perhitungan berdasarkan gejala-gejala yang telah diinputkan oleh pengguna pada Gambar 2 adalah dengan mengalikan 2 nilai bobot yaitu bobot yang diberikan oleh pengguna dengan rule pada Tabel III atau nilai bobot aturan yang diberikan oleh pakar. Hasil perkalian bobot gejala pengguna dengan pakar ditunjukkan pada Tabel IV.

Langkah selanjutnya adalah kombinasi hasil perkalian setiap gejala dari hasil kali pada Tabel IV. Kombinasi setiap gejala ditunjukkan pada Tabel V. Kombinasi hanya dapat dilakukan pada 2 atau lebih nilai CF. Pembobotan nilai maksimum pada penelitian ini adalah 1,0. Berdasarkan hasil akhir kombinasi Tabel V maka penyakit yang dialami oleh pasien A adalah Sinusitis dengan nilai keyakinan sebesar 0,917. Penyakit yang dialami oleh pasien B adalah Serumen (Kotoran Telinga) dengan nilai keyakinan sebesar 0,951 . Penyakit yang dialami oleh pasien $\mathrm{C}$ adalah Otitis Eksterna (OE) dengan nilai keyakinan sebesar 0,963. Penyakit yang dialami oleh pasien D adalah Rhinitis Kronis dengan nilai keyakinan sebesar 0,962 .

\section{E. Uji Pakar}

Uji pakar dilakukan untuk mengetahui ketepatan antara gejala-gejala yang diberikan oleh pakar dengan gejala-gejala yang berada dalam sistem beserta hasil diagnosa. Hasil diagnosa oleh sistem sesuai dengan hasil yang diberikan oleh pakar. Diagnosa pakar ditunjukkan pada Gambar 4.

\section{PENUTUP}

Metode CF dapat diimplementasikan dalam sistem pakar untuk diagnosa penyakit THT berdasarkan gejala-gejala yang diinputkan. Sistem pakar penyakit THT dapat digunakan dengan baik, dibuktikan dengan adanya uji pakar bahwa diagnosa dari sistem pakar penyakit THT memiliki hasil yang sama. Penelitian selanjutnya dapat dilakukan perbandingan antara metode $\mathrm{CF}$ dengan metode lain, sehingga dapat diketahui ketepatan hasil diagnosa pada tiap metode yang digunakan. Sebagai contoh penelitian terkait perbandingkan hasil diagnosa dari sistem pakar adalah perbandingan penggunaan metode CF dan metode Dempster Shafer [14] ataupun metode Bayesian Network dan Dempstes-Shafer pada sistem pakar diagnosa penyakit mata [15].

TABEL V. Kombinasi Hasil Perkalian Tiap Gejala

\begin{tabular}{|c|c|c|c|}
\hline \multicolumn{4}{|c|}{ Pasien A } \\
\hline \multicolumn{2}{|r|}{ Kemungkinan 1 = Sinusitis } & \multicolumn{2}{|c|}{ Kemungkinan 2 = Rhinitis Kronis } \\
\hline Iterasi & $\mathrm{CF} 1+(\mathrm{CF} 2 *(1-\mathrm{CF} 1))$ & Iterasi & $\mathrm{CF} 1+(\mathrm{CF} 2 *(1-\mathrm{CF} 1))$ \\
\hline 1 & $0,48+(0,24 *(1-0,48))=0,604$ & 1 & $0,24+(0,64 *(1-0,24))=0,726$ \\
\hline 2 & $0,604+(0,48 *(1-0,604))=0,794$ & 2 & $0,726+(0,60 *(1-0,726)=\mathbf{0 , 8 9 0}$ \\
\hline 3 & $0,794+(0,60 *(1-0,794))=\mathbf{0 , 9 1 7}$ & 3 & \\
\hline \multicolumn{4}{|c|}{ Pasien B } \\
\hline \multicolumn{2}{|c|}{ Kemungkinan 1 = Serumen } & \multicolumn{2}{|c|}{ Kemungkinan 2 = Otitis Eksterna } \\
\hline Iterasi & $\mathrm{CF} 1+(\mathrm{CF} 2 *(1-\mathrm{CF} 1))$ & Iterasi & $\mathrm{CF} 1+(\mathrm{CF} 2 *(1-\mathrm{CF} 1))$ \\
\hline 1 & $0,80+(0,64 *(1-0,80))=0,928$ & 1 & $0,48+(0,48 *(1-0,48))=0,729$ \\
\hline 2 & $0,928+(0,24 *(1-0,928))=0,945$ & 2 & $0,729+(0,64 *(1-0,729)=0,902$ \\
\hline 3 & $0,945+(0,12 *(1-0,945))=\mathbf{0 , 9 5 1}$ & 3 & $0,902+(0,48 *(1-0,902)=\mathbf{0 , 9 4 9}$ \\
\hline \multicolumn{4}{|c|}{ Pasien C } \\
\hline \multicolumn{2}{|c|}{ Kemungkinan 1 = Otitis Eksterna } & \multicolumn{2}{|c|}{ Kemungkinan 2 = Serumen } \\
\hline Iterasi & $\mathrm{CF} 1+(\mathrm{CF} 2 *(1-\mathrm{CF} 1))$ & Iterasi & $\mathrm{CF} 1+(\mathrm{CF} 2 *(1-\mathrm{CF} 1))$ \\
\hline 1 & $0,60+(0,48 *(1-0,60))=0,792$ & 1 & $0,80+(0,24 *(1-0,80))=0,848$ \\
\hline 2 & $0,792+(0,48 *(1-0,792))=0,892$ & 2 & $0,848+(0,12 *(1-0,848))=\mathbf{0 , 8 6 6}$ \\
\hline 3 & $0,892+(0,48 *(1-0,892))=\mathbf{0 , 9 4 4}$ & & \\
\hline \multicolumn{4}{|c|}{ Pasien D } \\
\hline \multicolumn{2}{|c|}{ Kemungkinan 1 = Rhinitis Kronis } & \multicolumn{2}{|c|}{ Kemungkinan $2=$ Sinusitis } \\
\hline Iterasi & $\mathrm{CF} 1+(\mathrm{CF} 2 *(1-\mathrm{CF} 1))$ & Iterasi & $\mathrm{CF} 1+(\mathrm{CF} 2 *(1-\mathrm{CF} 1))$ \\
\hline 1 & $0,80+(0,48 *(1-0,80))=0,896$ & 1 & $0,80+(0,64 *(1-0,80))=\mathbf{0 , 9 2 8}$ \\
\hline 2 & $0,896+(0,48 *(1-0,896))=0,945$ & & \\
\hline 3 & $0,945+(0,32 *(1-0,945))=\mathbf{0 , 9 6 2}$ & & \\
\hline
\end{tabular}




\begin{tabular}{|c|c|c|}
\hline \multicolumn{3}{|c|}{ Insil Dingnosis Dokter } \\
\hline Pasicin & Cejala & Diamnosa \\
\hline A & $\begin{array}{l}\text { 1. Batuk } \\
\text { 2. Sakit kepala } \\
\text { 3. Pilck } \\
\text { 4. Hidung mampet }\end{array}$ & cincisitis \\
\hline 11 & $\begin{array}{l}\text { 1. Telinga mampet } \\
\text { 2. Pondengarain berkurang } \\
\text { 3. Meniliki riwayat niengorek telinga } \\
\text { 4. Telingu gatal }\end{array}$ & \\
\hline C & $\begin{array}{l}\text { 1. Telinga nyeri } \\
\text { 2. Telinga gatal } \\
\text { 3. Memiliki riwayat mengorek telinga } \\
\text { 4. Telinga mainpet }\end{array}$ & \\
\hline D) & $\begin{array}{l}\text { 1. Pilek encer di keduit lidung } \\
\text { 2. Bersin } \\
\text { 3. Hidung imampot, sebelah, secara bergantian } \\
\text { 4. Sakit kepaila. }\end{array}$ & Rliinits tronis \\
\hline
\end{tabular}

Gambar 4. Diagnosa pakar

\section{REFERENSI}

[1] B. B. Gontung, O. I. Palendeng dan O. C. P. Palealu, "Pola Penyakit Penderita Rawat Inap di SMF THT-KL RSU PROF. DR. R. D. Kandou Periode Januari 2011 - Desember 2011,” Jurnal Kedokteran Komunitas dan Tropik, vol. III, no. 3, pp. 180-185, 2015.

[2] A. H. Posumah, R. H. Aji dan E. Loho, "Gambaran Foto Waters pada Penderita dengan Dugaan Klinis Sinusitis Maksilaris di Bagian Radiologi FK UNSRAT/SMF Radiologi BLU RSUP PROF. Dr. R. D. Kandou Manado Periode 1 Januari 2011-31 Desember 2011," Jurnal eBiomedik (eBM), vol. 1, no. 1, pp. 129-134, 2013.

[3] M. Dahria, "Pengembangan Sistem Pakar Dalam Membangun Suatu Aplikasi," Jurnal SAINTIKOM, vol. 10, no. 3, pp. 199-205, 2011.

[4] Y. Octavina dan A. Fadlil, "Sistem Pakar untuk Mendiagnosa Penyakit pada Saluran Pernafasan dan Paru menggunakan Metode Certainty Factor," Jurnal Sarjana Teknik Informatika, vol. 2, no. 2, pp. 1123-1132, 2014

[5] P. Wijayanti dan A. Fadlil, "Sistem Pakar Mendiagnosa Jenis Penyakit Stroke Menggunakan Metode Certainty Factor," Sarjana Teknik Informatika, vol. 2, no. 1, pp. 691-700, 2014.

[6] D. T. Yuwono, A. Fadlil dan Sunardi, "Penerapan Metode Forward Chaining dan Certainty Factor pada Sistem Pakar Diagnosa Hama Anggrek Coelogyne Pandurata," Ilmu Komputer (KLIK), vol. 04, no. 02, pp. 136-145, 2017.

[7] Tuswanto dan A. Fadlil, "Sistem Pakar untuk Mendiagnosa Hama dan Penyakit Tanaman Bawang Merah menggunakan Certainty Factor," Jurnal Sarjana Teknik Informatika, vol. 1, no. 1, pp. 21-31, 2013.
[8] S. Triyanto dan A. Fadlil, "Sistem Pakar untuk Mendiagnosa Penyakit Kelinci Berbasis Web," Jurnal Sarjana Teknik Informatika, vol. 2, no. 1, pp. 701-711, 2014.

[9] H. T. Sihotang, "Sistem Pakar untuk Mendiagnosa Penyakit Tanaman Jagung dengan Metode Bayes," Journal of Informatic Pelita Nusantara, vol. 3, no. 1, pp. 17-22, 2018.

[10] Lisnawita, L. L. V. FC dan E. Lindra, "Sistem Pakar Diagnosa Penyakit THT," Jurnal Inovtek Polbeng, vol. 1, no. 2, pp. 95-99, 2016.

[11] Suraya, "Sistem Pakar Untuk Mendiagnosa Penyakit THT Berdasarkan Gejalanya Untuk Menentukan Alternatif Pengobatan Menggunakan Tanaman Obat," Teknik Informatika, vol. III, no. 1, pp. 337-346, 2012.

[12] S. T, E. Mulyanto dan V. Suhartono, Kecerdasan Buatan, Yogyakarta: Andi, 2010

[13] Kusrini, Sistem Pakar Teori dan Aplikasi, Yogyakarta: CV Andi Offset, 2006.

[14] L. Ardila, "Analisis Perbandingan Hasil Antara Metode Certainty Factor dan metode Dempster Shafer dalam Sistem Pakar," Universitas Sumatera Utara, Medan, 2015.

[15] L. K. Wardhani dan R. Kurniawan, "Analisis Perbandingan Metode Bayesian Network dan Dempster-Shafer pada Sistem Pakar Diagnosis Penyakit Mata," dalam Seminar Nasional Teknologi Informasi Komunikasi dan Industri (SNTIKI) 4, Pekanbaru, 2012. 